\title{
Fragmentation patterns in the electron impact mass spectra of 1,3,5-triazin-2-one derivatives
}

\author{
Perry T. Kaye ${ }^{*}$ and Xolani W. Nocanda \\ Department of Chemistry, Rhodes University, P.O. Box 94, Grahamstown, 6140, South Africa. \\ Tel: +2746 6038254; Fax: +27466225109 \\ *Correspondence should be addressed to: \\ Professor P. T. Kaye, Department of Chemistry, Rhodes University, Grahamstown, 6140, South \\ Africa. Tel: +27 46 6038254; Fax: +27 466225109 \\ E-mail: P.Kaye@ru.ac.za
}

\begin{abstract}
Fragmentation patterns in the electron impact (EI) mass spectra of a series of 5-substituted 1,3,5triazin-2-ones, prepared from the reaction of dimethylolurea with selected primary amines, have been elucidated using a combination of high-resolution, comparative low-resolution and metastable peak analysis. In addition to characteristic fragmentations, in which the triazine nucleus remains intact, the 5-substituted 1,3,5-triazin-2-ones appear to exhibit a series of extrusion/ring-contraction processes, resulting in the formation of 3- and 4-membered ring fragments. Resonance-stabilised even-electron ions, arising, in each case, from loss of a hydrogen atom from the molecular ion, are considered pivotal in the formation of these heterocyclic fragments.
\end{abstract}

Keywords: Triazinone, mass spectrometry, fragmentation patterns

\section{Introduction}

The emission of formaldehyde from urea-formaldehyde (UF) resins ${ }^{1}$ may be reduced by decreasing the formaldehyde content ${ }^{2}$ and adding cross-linking agents such as ammonia or melamine during the resinification process. The inclusion of ammonia has been found to result in the formation of triazine-urea-formaldehyde resins, the presence of three reactive sites in the triazine nucleus permitting cross-linking. ${ }^{3}$ While the mass spectra of 1,3,5-triazines have been investigated, ${ }^{4}$ to our knowledge, no such studies of 1,3,5-triazin-2-ones have been reported. As 
part of a study of UF resins, ${ }^{5}$ we have prepared a series of 5-substituted 1,3,5-triazin-2-ones and, here, we discuss the electron impact (EI) mass spectra of the latter systems.

\section{Results and Discussion}

The triazinones 3-8 were prepared, following Burke's method, ${ }^{6}$ from dimethylolurea 1 and the corresponding primary amines 2 (Scheme 1). A combination of high-resolution, comparative low-resolution and metastable peak data was used to explore the fragmentation of these compounds. Selected MS data are summarised in Table 1 and the proposed fragmentation pathways are outlined in Schemes 2 and 3.

Table 1. Selected peaks ( $\mathrm{m} / \mathrm{z}$; followed, in parentheses, by \% relative abundance) from EI mass spectra of 1,3,5-triazin-2-ones 3-8, classified according to ion types A-I (Scheme 2)

\begin{tabular}{|c|c|c|c|c|c|c|c|c|c|c|c|c|}
\hline Compd & $\mathrm{R}^{1}$ & $\mathrm{R}^{2}$ & $\mathrm{R}^{3}$ & A & B & C & D & E & $\mathbf{F}$ & G & $\mathbf{H}$ & I \\
\hline 3 & $\mathrm{Me}$ & $\mathrm{H}$ & $\mathrm{H}$ & $\begin{array}{l}129^{\mathrm{a}} \\
(23.1)\end{array}$ & $\begin{array}{l}128^{\mathrm{a}} \\
(100.0)\end{array}$ & $\begin{array}{l}114^{\mathrm{a}} \\
(5.2)\end{array}$ & $\begin{array}{l}100^{\mathrm{b}} \\
(2.4)\end{array}$ & $-^{\mathrm{c}}$ & $\begin{array}{l}83^{b} \\
(5.5)\end{array}$ & $\begin{array}{l}99^{\mathrm{a}} \\
(15.8)\end{array}$ & $\begin{array}{l}85^{\mathrm{a}} \\
(21.9)\end{array}$ & $\begin{array}{l}56^{\mathrm{a}} \\
(7.6)\end{array}$ \\
\hline 4 & $\mathrm{Me}$ & $\mathrm{H}$ & $\mathrm{Me}$ & $\begin{array}{l}143^{\mathrm{a}} \\
(13.0) \mathrm{d}\end{array}$ & $\begin{array}{l}142^{\mathrm{b}} \\
(28.7)\end{array}$ & $\begin{array}{l}128^{\mathrm{a}} \\
(100) \mathrm{d}\end{array}$ & $\begin{array}{l}100^{\mathrm{b}} \\
(2.6)\end{array}$ & $\begin{array}{l}85^{\mathrm{b}} \\
(9.9)\end{array}$ & $\begin{array}{l}83^{b} \\
(3.6)\end{array}$ & $\begin{array}{l}113^{\mathrm{b}} \\
(10.6)\end{array}$ & $\begin{array}{l}99^{\mathrm{a}} \\
(24.2) \mathrm{d}\end{array}$ & $\begin{array}{l}56^{\mathrm{b}} \\
(62.8)\end{array}$ \\
\hline 5 & $\mathrm{Me}$ & $\mathrm{Me}$ & $\mathrm{Me}$ & $\begin{array}{l}157^{\mathrm{a}} \\
(8.7)\end{array}$ & $\begin{array}{l}156^{\mathrm{a}} \\
(5.5)\end{array}$ & $\begin{array}{l}142^{\mathrm{a}} \\
(88.2)\end{array}$ & $\begin{array}{l}100^{\mathrm{a}} \\
(13.0)\end{array}$ & $\begin{array}{l}85^{\mathrm{a}} \\
(3.3)\end{array}$ & $\begin{array}{l}83^{b} \\
(2.5)\end{array}$ & $\begin{array}{l}127^{\mathrm{b}} \\
(0.5)\end{array}$ & $\begin{array}{l}113^{\mathrm{b}} \\
(17.3)\end{array}$ & $\begin{array}{l}56^{\mathrm{a}} \\
(6.7)\end{array}$ \\
\hline 6 & $\operatorname{Pr}$ & $\mathrm{H}$ & $\mathrm{H}$ & $\begin{array}{l}157^{\mathrm{a}} \\
(39.8)\end{array}$ & $\begin{array}{l}156^{\mathrm{a}} \\
(60.7)\end{array}$ & $\begin{array}{l}114^{\mathrm{a}} \\
(100)\end{array}$ & $\begin{array}{l}100^{\mathrm{a}} \\
(4.5)\end{array}$ & $\begin{array}{l}85^{\mathrm{a}} \\
(63.9)\end{array}$ & $\begin{array}{l}83^{b} \\
(2.8)\end{array}$ & $\begin{array}{l}127^{\mathrm{a}} \\
(17.1)\end{array}$ & $\begin{array}{l}113^{\mathrm{a}} \\
(19.0)\end{array}$ & $\begin{array}{l}56^{\mathrm{a}} \\
(15.2)\end{array}$ \\
\hline 7 & $\mathrm{CH}_{2} \mathrm{OH}$ & $\mathrm{H}$ & $\mathrm{H}$ & $\begin{array}{l}145^{\mathrm{a}} \\
(3.6) \mathrm{d}\end{array}$ & $\begin{array}{l}144^{\mathrm{a}} \\
(23.1) \mathrm{d}\end{array}$ & $\begin{array}{l}114^{\mathrm{a}} \\
(100) \mathrm{d}\end{array}$ & $\begin{array}{l}100^{\mathrm{b}} \\
(2.4)\end{array}$ & $\begin{array}{l}85^{\mathrm{a}} \\
(86.6) \mathrm{d}\end{array}$ & $\begin{array}{l}83^{b} \\
(5.4)\end{array}$ & $\begin{array}{l}115^{\mathrm{b}} \\
(64.0)\end{array}$ & $\begin{array}{l}101^{\mathrm{b}} \\
(13.0)\end{array}$ & $\begin{array}{l}56^{\mathrm{b}} \\
(64.8)\end{array}$ \\
\hline 8 & $\mathrm{Ph}$ & $\mathrm{H}$ & $\mathrm{H}$ & $\begin{array}{l}191^{\mathrm{a}} \\
(2.4) \\
\end{array}$ & $\begin{array}{l}190^{\mathrm{a}} \\
(12.5) \\
\end{array}$ & $\begin{array}{l}190^{\mathrm{a}} \\
(0.9) \\
\end{array}$ & $\begin{array}{l}100^{\mathrm{a}} \\
(45.4) \\
\end{array}$ & $\begin{array}{l}85^{\mathrm{a}} \\
(1.3) \\
\end{array}$ & $\begin{array}{l}83^{\mathrm{b}} \\
(5.8) \\
\end{array}$ & $\begin{array}{l}161^{\mathrm{a}} \\
(1.5) \\
\end{array}$ & $\begin{array}{l}147^{\mathrm{a}} \\
(4.4)\end{array}$ & $\begin{array}{l}56^{\mathrm{a}} \\
(2.6) \\
\end{array}$ \\
\hline
\end{tabular}

${ }^{a}$ Atomic composition of fragment confirmed by high resolution analysis; \% relative abundance from high-resolution spectrum. ${ }^{b}$ Low-resolution MS data. ${ }^{c}$ In this case, ion $\mathbf{E}$ has same nominal mass ( $\mathrm{m} / \mathrm{z} 85)$ as fragment $\mathbf{H} .{ }^{\mathrm{d}} \%$ Relative abundance from low-resolution spectrum.

In all cases, loss of a hydrogen atom or an alkyl radical $\left(\mathrm{R}^{1} \$\right)$ from the 5 -substituent of the 
molecular ion A would account for the corresponding even-electron species B' and C (Scheme 2).

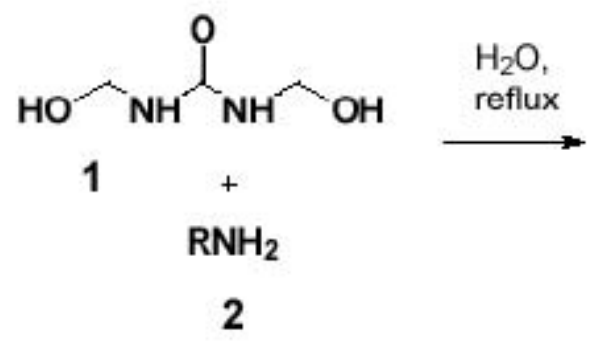

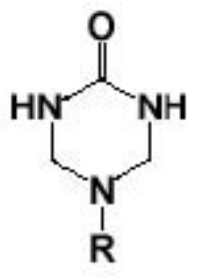

$3-8$

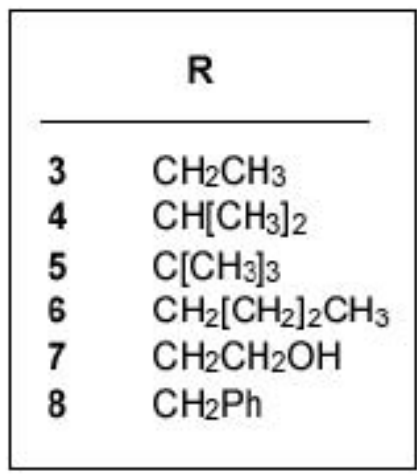

\section{Scheme 1}

However, loss of a ring hydrogen would afford fragments of type $\mathbf{B}$, in which delocalisation may be extended by involvement of the $\mathrm{N}(5)$ lone pair; consequently, ions of structural type B are considered more likely than the isomeric systems B'. Loss of the 5-substituent itself leads to the formation of cation $\mathbf{D}(\mathrm{m} / \mathrm{z} 100)$, which is common to all of the compounds examined; there is, in fact, metastable peak evidence for the direct formation of cation $\mathbf{D}$ from both the molecular ion A and the M-1 fragment $\mathbf{B}$.

In addition to the foregoing fragmentations, in which the triazine nucleus remains intact, the 5-substituted 1,3,5-triazin-2-ones 3-8 appear to exhibit a series of extrusion/ring-contraction processes, resulting in the formation of 3- and 4-membered ring fragments. The resonancestabilised cations $\mathbf{B}$ are considered pivotal in the formation of these heterocyclic fragments (E-I). Thus, elimination of a neutral imine $\left(\mathrm{R}_{2} \mathrm{C}=\mathrm{NR}\right)$ from the cation $\mathbf{B}$ would afford, in each case, the common, diazolium ion $\mathbf{E}(\mathrm{m} / \mathrm{z}$ 85) (see Figure 1a), dehydrogenation of which gives cation $\mathbf{F}$ $(\mathrm{m} / \mathrm{z} 83)$. On the other hand, extrusion of the neutral molecules, $\mathrm{CH}_{2}=\mathrm{NH}$ or $\mathrm{HN}=\mathrm{C}=\mathrm{O}$, from cations of type $\mathbf{B}$ would afford fragments which retain the 5-alkyl substituent and which have been tentatively formulated as the diazetinones $\mathbf{G}$ and their deoxo analogues $\mathbf{H}$, respectively. Access to these latter ions ( $\mathbf{G}$ and $\mathbf{H}$ ) is attributed to the similar, but fragment-specific eliminations depicted in Figures $1 \mathrm{~b}$ and 1c; while there is metastable peak support for the fragmentation, BG, there is similar evidence, in some cases, for the loss of $\mathrm{CH}_{3} \mathrm{NH}$ \$ from the molecular ion, i.e. AG. Elimination of a moiety containing the 5-substituent (Figure 1d) would account for the common cation at $\mathrm{m} / \mathrm{z} 56$, tentatively formulated as the aziriniminium species $\mathbf{I}$. 


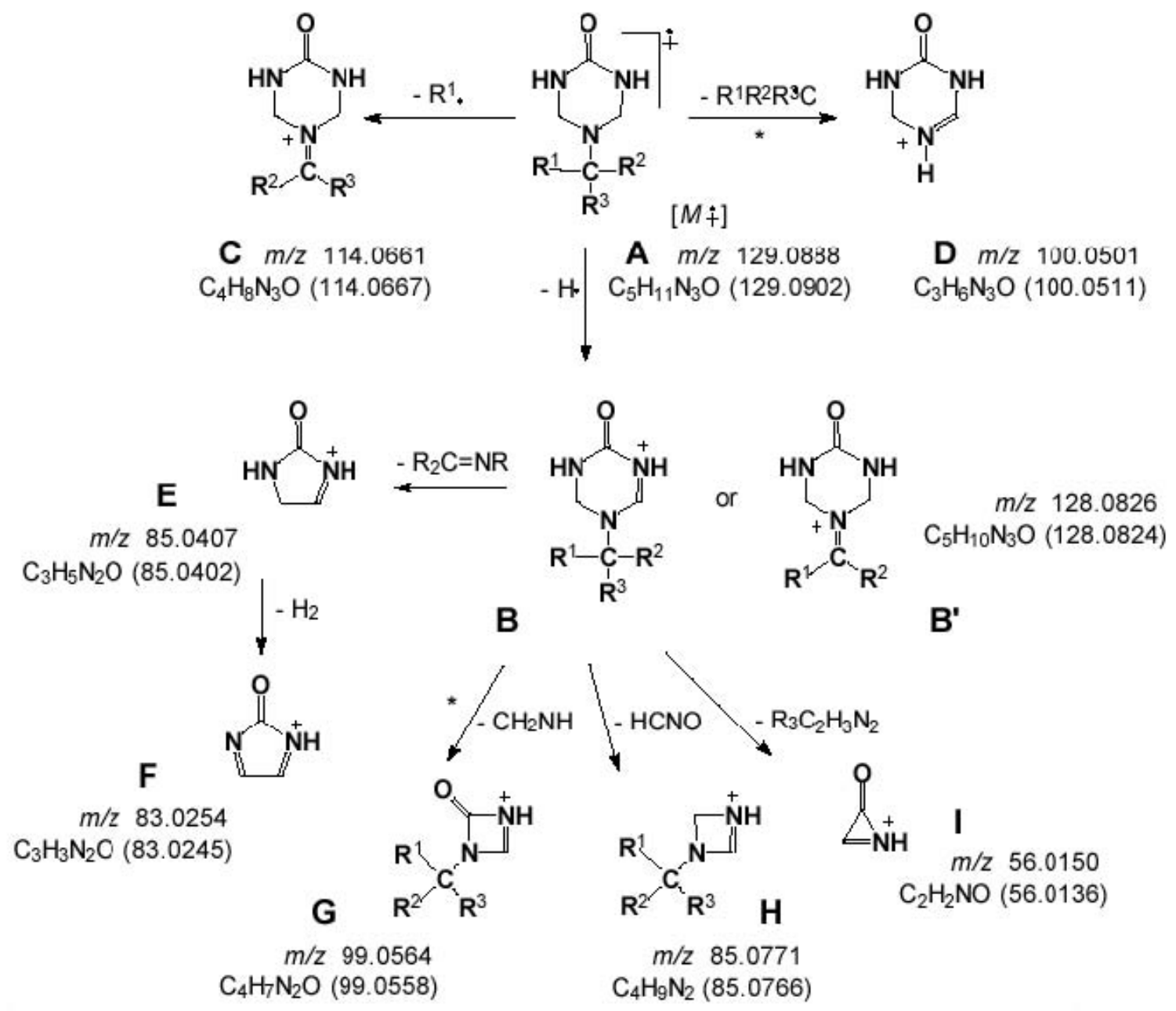

Scheme 2

Mass-spectral fragmentation pathways for the 1,3,5-triazin-2-ones 3 - 8. Accurate masses $(\mathrm{m} / \mathrm{z})$ are followed, in parentheses, by calculated formula masses for compound $\mathbf{3}\left(\mathrm{R}^{1}=\mathrm{Me}, \mathrm{R}^{2}=\mathrm{R}^{3}=\right.$ $\mathrm{H})$; an asterisk indicates a pathway supported by metastable peak data.

Accurate masses $(\mathrm{m} / \mathrm{z})$ are followed, in parentheses, by calculated formula masses; an asterisk indicates a pathway supported by metastable peak data.

The 5-benzyl derivative 8, not surprisingly, exhibits a number of additional, characteristic fragmentations, all of which are supported by high-resolution data (Scheme 3). The base peak, in this case, corresponds to the tropylium cation $\mathbf{M}(\mathrm{m} / \mathrm{z} 91)$, metastable peak data supporting its formation via the sequence, AGM. 


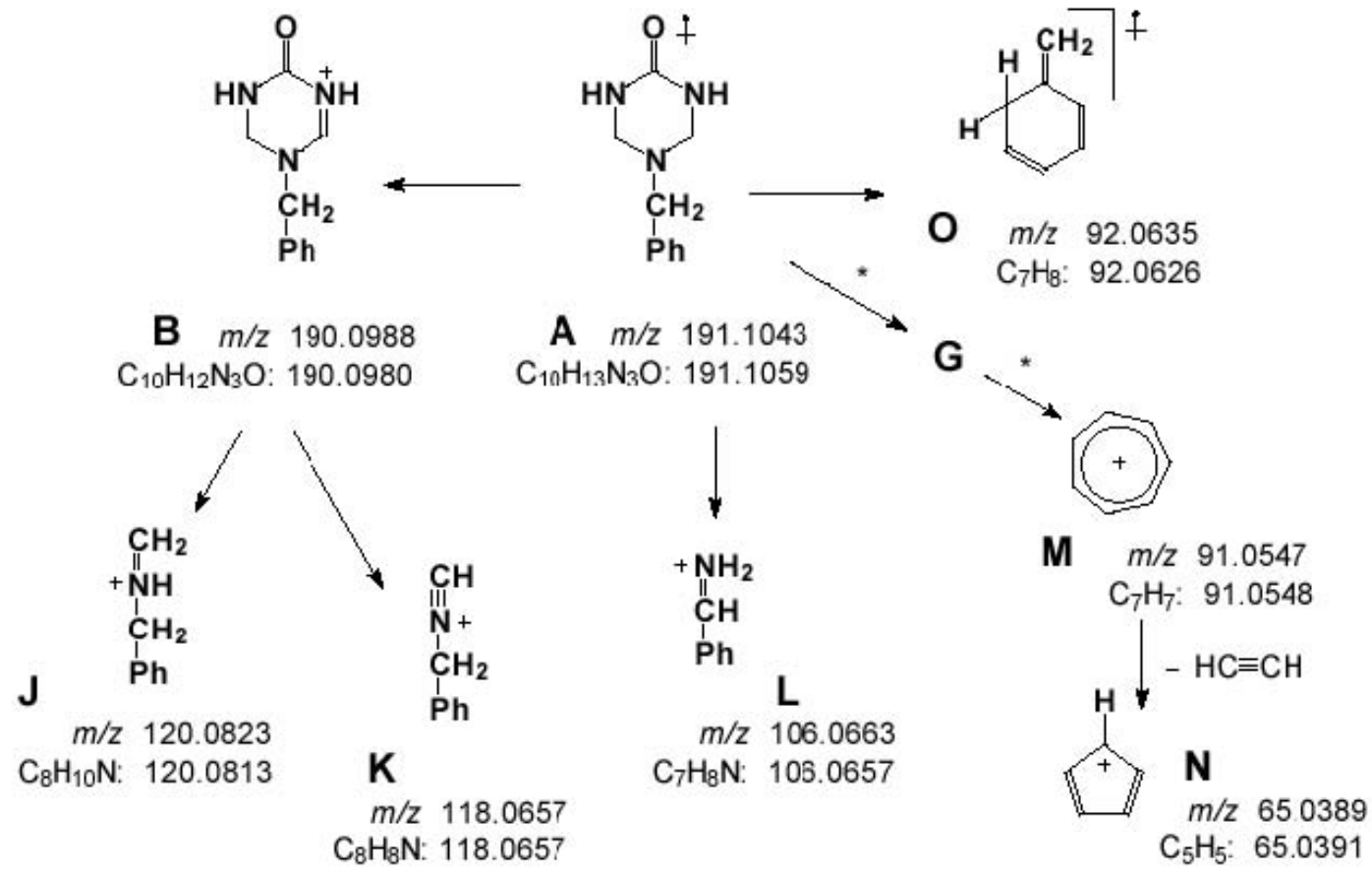

\section{Scheme 3}

Additional mass-spectral fragmentation pathways for 5-benzyl-1,3,5-triazin-2-one 8.

(a)

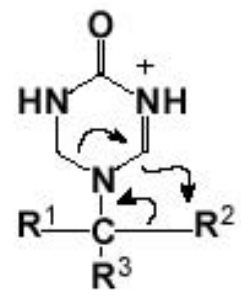

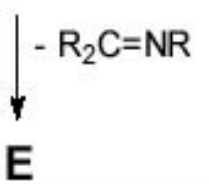

(b)
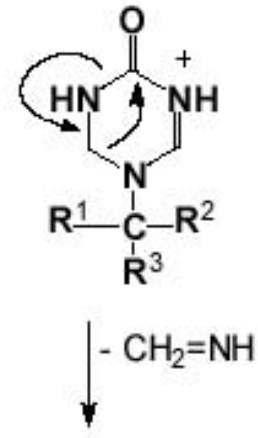

G (d)
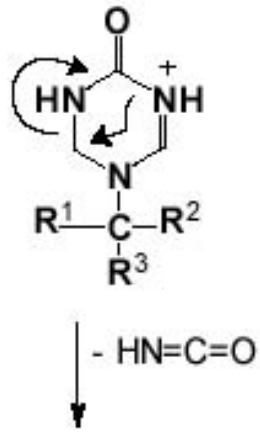

H (d)
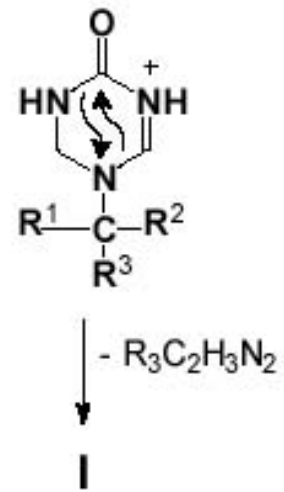

Figure1. Proposed fragmentations of the cations of type $\mathbf{B}$ to account for the formation of the heterocyclic fragments, E, G, $\mathbf{H}$ and $\mathbf{I}$. 


\section{Experimental Section}

General Procedures. NMR spectra were recorded in $\mathrm{CDCl}_{3}$ on a Bruker AMX 400 NMR spectrometer and referenced using the solvent signals $\left(\delta_{\mathrm{H}} 7.25\right.$ and $\left.\delta_{\mathrm{C}} 77.0 \mathrm{ppm}\right)$. Lowresolution mass spectra were obtained on Hewlett-Packard 5988A and Finnigan Mat GCQ mass spectrometers. High-resolution EI data were collected on a VG-70SEQ mass spectrometer equipped with an MSS MASPEC II/32 data station (Cape Technikon Mass Spectrometry Unit), using high-resolution magnetic scans and B/E metastable scanning. Dimethylourea 1 [m.p. 129$130{ }^{\circ} \mathrm{C}$ (lit. ${ }^{7} 126-129^{\circ} \mathrm{C}$ )] was prepared following a reported method. ${ }^{7}$ The synthesis of the $1,3,5$ triazone derivatives, of which compounds $3^{8}$ and $7\left[158-159{ }^{\circ} \mathrm{C}\left(\right.\right.$ lit. $\left.\left.^{6} 158{ }^{\circ} \mathrm{C}\right)\right]$ are known, is illustrated by the following example.

5-(2-hydroxyethyl)hexahydro-1,3,5-triazin-2-one (7). 2-Aminoethanol (2.5 ml, $0.042 \mathrm{~mol})$ was added, with cooling, to dimethylolurea 1 (5 .0 g, $0.042 \mathrm{~mol})$ in water $(7 \mathrm{ml})$. The resulting solution was heated at $90-100{ }^{\circ} \mathrm{C}$ for two hours and then kept at room temperature overnight. The reaction mixture was concentrated under reduced pressure, and the solid residue recrystallised twice from ethanol to afford 5-(2-hydroxyethyl)hexahydro-1,3,5-triazin-2-one 7 (2.9 g, 47 \%), (Found: $\mathbf{M}^{+}$145.0853. Calc. for $\left.\mathrm{C}_{5} \mathrm{H}_{11} \mathrm{~N}_{3} \mathrm{O}_{2}: M, 145.0851\right) ; v_{\max }\left(\mathrm{KBr} / \mathrm{cm}^{-1}\right) 3320$ $(\mathrm{OH}), 3220(\mathrm{NH})$ and $1660(\mathrm{CO}) ; \delta_{\mathrm{H}}(400 \mathrm{MHz}$; DMSO-d 6$) 2.65\left(2 \mathrm{H}, \mathrm{t}, 1^{\prime}-\mathrm{CH}_{2}\right), 3.50(2 \mathrm{H}$, m,2'- $\left.\mathrm{CH}_{2}\right), 3.99\left(4 \mathrm{H}, \mathrm{s}, 2 \mathrm{xCH} \mathrm{CH}_{2}\right), 4.51\left(\mathrm{HH}\right.$, br s, OH) and $6.27\left(2 \mathrm{H}\right.$, br s, NH); $\delta_{\mathrm{C}}(100 \mathrm{MHz}$; DMSO-d $\left.{ }_{6}\right) 52.1\left(1^{\prime}-\mathrm{CH}_{2}\right), 59.7\left(2^{\prime}-\mathrm{CH}_{2}\right), 61.6\left(2 \times \mathrm{CH}_{2}\right)$ and $154.7(\mathrm{CO}) ; \mathrm{m} / \mathrm{z} 145\left(\mathrm{M}^{+}, 3.6 \%\right)$ and $114(100)$.

Analytical data for the new 1,3,5-traizinone derivatives prepared in this study are as follows.

5-Ethylhexahydro-1,3,5-triazin-2-one (3). ${ }^{8}$ (2.0 g, 19 \%), m.p. 156-158 ${ }^{\circ} \mathrm{C}$. (Found: $\mathbf{M}^{+}$ 129.0910. $\mathrm{C}_{5} \mathrm{H}_{11} \mathrm{~N}_{3} \mathrm{O}$ requires: $\left.M, 129.0902\right) ; v_{\max }\left(\mathrm{KBr} / \mathrm{cm}^{-1}\right) 3220(\mathrm{NH})$ and1650 (CO); $\delta_{\mathrm{H}}(400$ MHz; DMSO-d $\left.{ }_{6}\right) 1.03\left(3 \mathrm{H}, \mathrm{t}, \mathrm{CH}_{3}\right), 2.61\left(2 \mathrm{H}, \mathrm{q}, 1^{\prime}-\mathrm{CH}_{2}\right), 3.99\left(4 \mathrm{H}, \mathrm{d}, 2 \mathrm{xCH}_{2}\right)$ and $6.15(2 \mathrm{H}$, br $\mathrm{s}, \mathrm{NH}) ; \delta_{\mathrm{C}}(100 \mathrm{MHz}$; DMSO-d $) 13.0\left(\mathrm{CH}_{3}\right), 43.1\left(1^{\prime}-\mathrm{CH}_{2}\right), 60.4\left(2 \mathrm{xCH}_{2}\right)$ and $154.8(\mathrm{CO}) ; \mathrm{m} / \mathrm{z}$ $129\left(\mathrm{M}^{+}, 30.2 \%\right)$ and $128(100)$.

5-Isopropylhexahydro-1,3,5-triazin-2-one (4). (1.9 g, 51 \%), m.p.179-180 ${ }^{\circ} \mathrm{C}$. (Found: $\mathbf{M}^{+}$ 143.1064 $\mathrm{C}_{6} \mathrm{H}_{13} \mathrm{~N}_{3} \mathrm{O}$ requires: $\left.M, 143.1058\right)$; $v_{\max }$ (hexachlorobutadiene mull / $\left.\mathrm{cm}^{-1}\right) 3226(\mathrm{NH})$ and $1673(\mathrm{CO}) ; \delta_{\mathrm{H}}\left(400 \mathrm{MHz}\right.$; DMSO- $\left.d_{6}\right) 1.05\left(6 \mathrm{H}, \mathrm{d}, 2 \mathrm{xCH}_{3}\right), 2.93(1 \mathrm{H}$, septet, $\mathrm{CH}), 4.06(4 \mathrm{H}$, $\left.\mathrm{d}, 2 \mathrm{xCH}_{2}\right)$ and $6.18\left(2 \mathrm{H}\right.$, br s, NH); $\delta_{\mathrm{C}}(100 \mathrm{MHz}$; DMSO-d $) 21.0\left(2 \mathrm{xCH}_{3}\right), 45.9(\mathrm{CH}), 58.5$ $\left(2 \mathrm{xCH}_{2}\right)$ and $155.0(\mathrm{CO}) ; \mathrm{m} / \mathrm{z} 143\left(\mathrm{M}^{+}, 13.0 \%\right)$ and $128(100)$. 
5-t-Butylhexahydro-1,3,5-triazin-2-one (5). (2.7 g, 41 \%), m.p. 181-182 ${ }^{\circ} \mathrm{C}$. (Found: $\mathbf{M}^{+}$ 157.1209. $\mathrm{C}_{7} \mathrm{H}_{15} \mathrm{~N}_{3} \mathrm{O}$ requires: $\left.M, 157.1215\right) ; v_{\max }\left(\mathrm{KBr} / \mathrm{cm}^{-1}\right) 3220(\mathrm{NH})$ and1690 $(\mathrm{CO}) ; \delta_{\mathrm{H}}$ $\left.\left(400 \mathrm{MHz} ; \mathrm{DMSO}-d_{6}\right) 28.2\left(3 \mathrm{xCH}_{3}\right), 52.9\left[\left(\mathrm{CH}_{3}\right)_{3} \mathrm{C}\right)\right], 56.7\left(2 \mathrm{xCH}_{2}\right)$ and $155.4(\mathrm{CO}) ; \mathrm{m} / \mathrm{z} 157$ $\left(\mathrm{M}^{+}, 11.6 \%\right)$ and $58(100)$

5-Butylhexahydro-1,3,5-triazin-2-one (6). (1.5 g, 23 \%), m.p.128-130 ${ }^{\circ} \mathrm{C}$ (Found: $\mathbf{M}^{+}$ 157.1218. $\mathrm{C}_{7} \mathrm{H}_{15} \mathrm{~N}_{3} \mathrm{O}$ requires: $\left.M, 157.1215\right)$; $v_{\max }$ (hexachlorobutadiene mull $\left./ \mathrm{cm}^{-1}\right) 3223(\mathrm{NH})$ and $1666(\mathrm{CO}) ; \delta_{\mathrm{H}}(400 \mathrm{MHz} \text {; DMSO-d })_{6} 0.88\left(3 \mathrm{H}, \mathrm{t}, \mathrm{CH}_{3}\right), 1.32\left(2 \mathrm{H}, \mathrm{m}, \mathrm{CH}_{3} \mathrm{CH}_{2}\right), 1.40(2 \mathrm{H}$, $\left.\mathrm{m}, \mathrm{NCH}_{2} \mathrm{CH}_{2}\right), 2.55\left(2 \mathrm{H}, \mathrm{t}, \mathrm{NCH}_{2} \mathrm{CH}_{2}\right), 3.97\left(4 \mathrm{H}, \mathrm{d}, 2 \mathrm{xCH}_{2}\right)$ and $6.25(2 \mathrm{H}, \mathrm{br} \mathrm{s}, \mathrm{NH}) ; \delta_{\mathrm{C}}(100$ MHz; DMSO-d $\left.d_{6}\right) 13.7\left(\mathrm{CH}_{3}\right), 19.8,29.5$ and $48.8\left(\left[\mathrm{CH}_{2}\right]_{3}\right), 60.8\left(2 \mathrm{xCH}_{2}\right)$ and $154.7(\mathrm{CO}) ; \mathrm{m} / \mathrm{z}$ $157\left(\mathrm{M}^{+}, 27.5 \%\right)$ and $42(100)$.

5-Benzylhexahydro-1,3,5-triazin-2-one (8). (0.4 g, 5 \%), m.p.190-192 ${ }^{\circ} \mathrm{C}$. (Found: $\mathbf{M}^{+}$ 191.1050. $\mathrm{C}_{10} \mathrm{H}_{13} \mathrm{~N}_{3} \mathrm{O}$ requires: $\left.M, 191.1058\right)$; $v_{\max }$ (hexachlorobutadiene mull $\left./ \mathrm{cm}^{-1}\right) 3062(\mathrm{NH})$ and $1681(\mathrm{CO}) ; \delta_{\mathrm{H}}(400 \mathrm{MHz}$; DMSO-d $) 3.78\left(2 \mathrm{H}, \mathrm{s}, \mathrm{CH}_{2} \mathrm{Ph}\right), 3.99\left(4 \mathrm{H}, \mathrm{d}, 2 \mathrm{xCH}_{2}\right), 6.35(2 \mathrm{H}$, br s, NH), 7.25 - $7.34(5 \mathrm{H}, \mathrm{ArH}) ; \delta_{\mathrm{C}}(100 \mathrm{MHz} \text {; DMSO-d })_{6} 53.3\left(\mathrm{CH}_{2} \mathrm{Ph}\right), 60.5\left(2 \mathrm{xCH}_{2}\right), 127.1$, 128.2, 128.7 and138.2 (ArC) and $154.6(\mathrm{CO}) ; \mathrm{m} / \mathrm{z} 191\left(\mathrm{M}^{+}, 0.9 \%\right)$ and $91(100)$.

\section{Acknowledgements}

We thank FORMALCHEM Ltd., Rhodes University and the National Research Foundation (NRF) for generous financial support, Mr. A. Sonemann (Rhodes University) for low-resolution MS data and Dr P. Boshoff (Cape Technikon) for high-resolution data.

\section{References}

1. Su, Y.; Quanyin, R.; Weizhong, W.; Xinwei, M. Thermochimica Acta, 1995, 253, 307.

2. Pizzi, A.; Lipschitz, L.; Valenzuela, J. Holzforschung, 1994, 48, 254.

3. Christjanson, P.; Siimer, K.; Suurpere, A. Tallina Tehnikaülik Toim., 1994, 744, 24.

4. Quirke, J. M. E. In Comprehensive Heterocyclic Chemistry, Eds. Katritzky, A. R.; Rees, C. W. Pergamon, Oxford, 1984, Vol. 3, p 465.

5. Nocanda, X. W. MSc thesis, Rhodes University, 1998.

6. Burke, W. J. J. Am. Chem. Soc. 1947, 69, 2136.

7. Ludlam, P. R. Analyst (London) 1973, 98, 107.

8. This compound has been reported as a component in a resin mixture, but does not appear to 
have been isolated or characterized previously. 